\title{
Life History and Courtship Behavior of Black Perch, Embiotoca jacksoni (Teleostomi: Embiotocidae), from Southern California ${ }^{1}$
}

\author{
Bridgette Froeschke, ${ }^{2}$ Larry G. Allen, ${ }^{2,4}$ and Daniel 7. Pondella II ${ }^{3}$
}

\begin{abstract}
The black perch, Embiotoca jacksoni Agassiz, 1853, is a common reef fish associated with nearshore marine habitats of California, with the majority of the population occurring within the Southern California Bight. Black perch were collected throughout southern California from Santa Barbara to Carlsbad, including Santa Catalina Island, to determine their physical characteristics, growth, sex ratio, periodicity of reproduction, and length of gestation. Courtship observations were conducted using scuba along the King Harbor Breakwater in Redondo Beach, California, from January 2004 to December 2005 to verify periodicity of courting and associated reproductive behaviors. Specimens captured ranged from 75 to $220 \mathrm{~mm}$ standard length and from 18 to $487 \mathrm{~g}$ in total body weight. Seven age-classes were determined by otolith aging, with the growth rate tapering off after age-class one. Seventy percent of the individuals captured were from age-classes one to three. Growth rates did not differ between sexes. Mean monthly gonosomatic indexes for males peaked from July to November, with the highest mean occurring in October. Gestating females were found from December to May, with youngest gestating females being in age-class one. Courtship behaviors were observed within aggregations and in pairs from July to November, with males being the primary aggressors. Courtship postures occurred along the base of the reef, with pairs departing into caves for copulation. This study suggests that the black perch population within the Southern California Bight has different life history characteristics and reproductive timing than those in northern California.
\end{abstract}

Surfaerches (Еmbiotocidae) are an ecologically important family of viviparous teleost fishes that occur along the eastern Pacific coast in California, Oregon, and Washington (DeMartini 1969). Nineteen of 23 species of surfperches occur along the California coast (Anderson and Bryan 1970, Leet et al. 2001) and are considered northern, temperate

\footnotetext{
${ }^{1}$ Financial support was provided by the Long Beach Aquarium of the Pacific, Sigma Xi, Vantuna Research Group, and the Nearshore Marine Fish Research Program. Manuscript accepted 12 December 2006.

2 Department of Biology, California State University Northridge, Northridge, California 91330-8303.

${ }^{3}$ Department of Biology, Occidental College, Los Angeles, California 90042.

${ }^{4}$ Corresponding author: larry.allen@csun.edu.
}

Pacific Science (2007), vol. 61, no. 4:521-531

(C) 2007 by University of Hawai'i Press

All rights reserved species (cold affinity [Holbrook et al. 1997, Horn et al. 2006]). They are found in a variety of habitats, including sandy and rocky reefs, intertidal and subtidal kelp beds, bays and estuaries, and eelgrass beds (Leet et al. 2001, Allen and Pondella 2006, Allen et al. 2006, Stephens et al. 2006). However, surfperch abundance has declined by up to $80 \%$ in California, probably as a result of increased ocean temperature (Holbrook et al. 1997) and commercial and recreational fishing (Karpov et al. 1995).

One of the most abundant surfperches off California is the black perch (Embiotoca jacksoni Agassiz, 1853), which ranges from Fort Bragg in northern California to central Baja California in Mexico (Miller and Lea 1972). Reports on the life history and reproductive behaviors of black perch have been sporadic (Carlisle et al. 1964, Isaacson and Isaacson 1966, Behrens 1977, Hixon 1981, Baltz 1984). Moreover, conflicting information on 
maturation, timing of reproduction, and reproductive behavior of black perch has appeared in the literature (Carlisle et al. 1964, Isaacson and Isaacson 1966, Behrens 1977, Hixon 1981, Baltz 1984).

Age and growth parameters were determined using the scale method for shiner perch, walleye surfperch, and white seaperch (Anderson and Bryan 1970). They reported that all three species grew fastest in length in their first year, with growth tapering off in later years. In addition, white seaperch had the fastest growth at any age and shiner perch had the slowest. Females grew faster than males and thus were longer than males in all three species, with the difference being apparent in 1-yr-old shiner perch but not until the second year of life for walleye surfperch and white seaperch. It was speculated that sexual dimorphism in size developed earlier in shiner perch than in the other two species because shiner perch matured earlier (Anderson and Bryan 1970). They also reported that males had a shorter life span in shiner perch and walleye surfperch, whereas white seaperch had the same life span in both sexes.

The purpose of the study reported here was to obtain data on various life history parameters and courtship behavior for black perch (E. jacksoni) throughout the Southern California Bight. Specifically, in this report we summarize information on length frequency, length-weight relationship, age and growth parameters, reproductive state, and behaviors of black perch in the Southern California Bight.

MATERIALS AND METHODS

\section{Collection of Specimens}

Black perch were collected monthly by spear, by gill nets in conjunction with Ocean Resources Enhancement and Hatchery Program (OREHP) sampling for juvenile white seabass, and from impingement studies of coastal generating stations in Redondo Beach and Carlsbad, California (Table 1). The following life history metrics were collected for each fish: standard length (SL) (mm), total length ( $\mathrm{mm})$, total body mass $(\mathrm{g})$, and gonad weight (g). Body mass and gonads were weighed to the nearest gram when specimens were worked up in the field or weighed to the nearest $0.001 \mathrm{~g}$ when brought to the laboratory.

Sex of each fish was determined using external characteristics (presence or absence of gonopodium) and state of gonads. For females, it was noted if the individual was gravid, and if so the number of embryos was recorded. The gonosomatic index (GSI) was calculated for males using the following equation: GSI = (gonad weight/gonad-free body weight $) \times 100($ Wiebe $1968 b)$.

\section{Age and Growth}

The sagittal otoliths were removed through the ventrum of the neurocranium (Craig et al. 1999). Length to the nearest $0.1 \mathrm{~mm}$, width to the nearest $0.1 \mathrm{~mm}$, and weight to the nearest $0.0001 \mathrm{~g}$ were determined for the left sagittal otolith for each fish. If the left otolith was broken or missing the right otolith was used. Otoliths were then mounted onto wood blocks with cyanoacrylate (superglue), and a $0.5-\mathrm{mm}$ cross section was cut through the focus using a low-speed saw (Buehler Isomet). Each cross section was placed in a watch glass with a black background, filled with distilled water, and read using a dissecting microscope at $50 \times$ and/or $25 \times$ magnification under reflected light. Annual rings were counted (an opaque band and a translucent band), and the outer edge was noted as being translucent (clear) or opaque (white). Each otolith was read independently twice, and when a discrepancy existed between the two readings a third blind reading was performed. Only three otoliths were excluded due to discrepancies among the three readings. FISHPARM (1989) was used to construct the growth curve for black perch overall and for males and females separately using the von Bertalanffy growth equation:

$$
L_{t}=L_{\infty}\left(1-e^{-K\left(t-t_{0}\right)}\right)
$$

where $L_{t}=$ predicted length at age $t$, $L_{\infty}=$ maximum predicted length by equation, $e=$ base of the natural $\log , K=$ growth rate constant, $t=$ age, $t_{0}=$ theoretical length at time zero. 
To obtain fish from all age classes, age was determined for all individuals smaller than $100 \mathrm{~mm}$ SL and larger than $190 \mathrm{~mm}$ SL. In addition, because of the large numbers of black perch collected ranging from 150 to $160 \mathrm{~mm}$ SL, for months (May, August, October, November) in which a high number of fish were collected, age was determined for 20 randomly chosen individuals. The weightlength relationship was calculated using the equation $W=a L^{b}$, where $W=$ weight $(\mathrm{g})$, $L=$ standard length $(\mathrm{mm})$. Constants ( $a$ and $b$ ) were determined using nonlinear regression in STATISTICA 7 (StatSoft 2007).

\section{Behavior}

Scuba observations in the field were conducted in King Harbor, Redondo Beach, along the west breakwater. Observations were conducted monthly until courting behavior was first observed; then observations were conducted weekly. Behavioral observations were made from January 2004 to December 2005; for both years weekly observations were made from late summer to early fall months. When conditions were not suitable at King Harbor due to a red tide (June 2005 through September 2005), observations were conducted at Palos Verdes and Santa Catalina Island (Pin Rock, Rock Quarry, and Empire Landing).

Observations were conducted covering a 100 -m span of the breakwater. Five $5 \times 5 \mathrm{~m}$ plots were established at $5-\mathrm{m}$ and $10-\mathrm{m}$ depths using cement blocks to outline the perimeters of plots along the breakwater. Black perch within each plot were observed from a minimum distance of $3 \mathrm{~m}$ for $5 \mathrm{~min}$ (DeMartini 1988), and courtship behaviors were noted. While courting was taking place, observations continued as long as the fish were visible. A minimum of three fish per plot were observed. If the fish being observed left the plot it was noted and divers observed another fish within the same plot. If black perch were not seen in a plot, divers remained and watched the plot for $15 \mathrm{~min}$ to ensure that one did not enter. Divers noted, when possible, the sex of the individual (presence or absence of gonopodium) and the types and frequency of behaviors, including courtship, aggressive, and feeding behaviors. In addition, divers noted any patterns related to body size, grouping fish into three size classes $(<100 \mathrm{~mm}$ SL [juveniles], $>100 \mathrm{~mm}$ SL to $<150 \mathrm{~mm}$ SL [subadults], and $>150 \mathrm{~mm} \mathrm{SL}$ [adults] [Ebeling and Laur 1985]).

Black perch were observed at various times of day at the Long Beach Aquarium of the Pacific weekly from June 2004 to January 2005 to better understand their behavioral postures, agonistic behaviors, and courtship behaviors before and during observations that were conducted in the field.

\section{Statistical Analyses}

The null hypotheses that the weight and length relationship and the growth rates did not differ between sexes were tested using Analysis of Covariance (ANCOVA) in SYSTAT 9 (SYSTAT Software 1999). Data were $\log _{10}(x+1)$ transformed to meet assumptions of linearity. In addition, the null hypothesis that there was no relationship between the number of embryos and the length of the female was tested using a linear regression in SYSTAT 9 (SYSTAT Software 1999). The null hypothesis that black perch did not differ from a 1:1 sex ratio was tested using a Goodness of fit test ( $G$-test).

\section{RESULTS}

\section{Abundance and Length Frequency}

A total of 641 black perch was collected from January through November 2004 and December 2005 through January 2006. Sixty-eight individuals were obtained from power plant impingement, 90 by spearing, and 483 from gill nets (Table 1). Sizes ranged from 75 to $220 \mathrm{~mm} \mathrm{SL}$ and from 18 to $487 \mathrm{~g}$ total body weight. Overall, $45 \%(n=275)$ of black perch ranged from 150 to $160 \mathrm{~mm}$ SL.

\section{Length-Weight Relationship}

The length-weight function for all fish pooled $(n=614)$ was $W=0.000085 L^{2.8636}$, and over $96 \%$ of the variance was explained by the model $\left(R^{2}=0.9629\right.$ [Figure 1]). The function did not differ significantly between 
TABLE 1

Number of Black Perch (Embiotoca jacksoni) Collected at Each Site throughout Southern California, Separated by Collection Method: Gill Nets, Spearing, and Impingement $($ Total $=641)$

\begin{tabular}{|c|c|c|c|c|}
\hline \multirow[b]{2}{*}{ Stations } & \multirow[b]{2}{*}{ Locations } & \multicolumn{3}{|c|}{ Catch Method } \\
\hline & & Gill Net & Spear & Impingement \\
\hline Carlsbad & Encina Power Plant & & & 40 \\
\hline San Onofre & SONGS & & & 4 \\
\hline Newport & Reef Pt. & 17 & & \\
\hline Santa Catalina Island & Salta Verde & 24 & & \\
\hline Santa Catalina Island & Empire Landing & & 11 & \\
\hline Santa Catalina Island & Catalina Harbor & 34 & & \\
\hline Santa Catalina Island & West Cove & 3 & & \\
\hline Seal Beach & Seal Beach & 3 & & \\
\hline Los Angeles Breakwater & LA Federal Breakwater & & 30 & \\
\hline Palos Verdes & Flat rock & 145 & 10 & \\
\hline Redondo Beach & Redondo Power Plant & & & 24 \\
\hline King Harbor & King Harbor & & 39 & \\
\hline Marina del Rey & Marina del Rey & 10 & & \\
\hline Malibu & Malibu Pt. & 58 & & \\
\hline Ventura & Pitas Pt. & 148 & & \\
\hline Santa Barbara & Campus Pt. & 20 & & \\
\hline Santa Barbara & Coal Oil Pt. & 21 & & \\
\hline Total & & 483 & 90 & 68 \\
\hline
\end{tabular}

males and females (ANCOVA, $F=0.12$; $\mathrm{df}=1,595 ; P=0.726)$.

Age and Growth

Annual bands were formed in the otoliths of black perch. The majority of the specimens

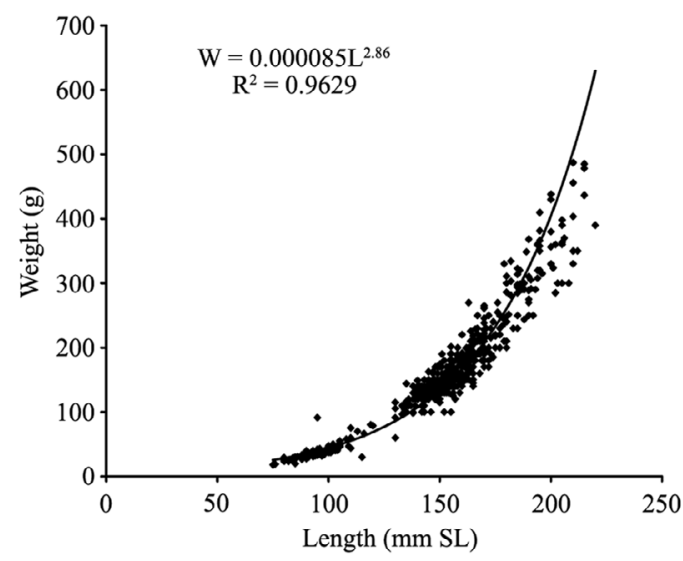

FIGURE 1. Length-weight relationship of black perch (Embiotoca jacksoni) collected from January 2004 through November 2004 and December 2005 through January 2006 from all southern California locations $(n=614)$. laid down opaque bands starting in spring and decreasing in late summer (Figure 2). Therefore, opaque bands followed by translucent bands appeared to represent annual rings.

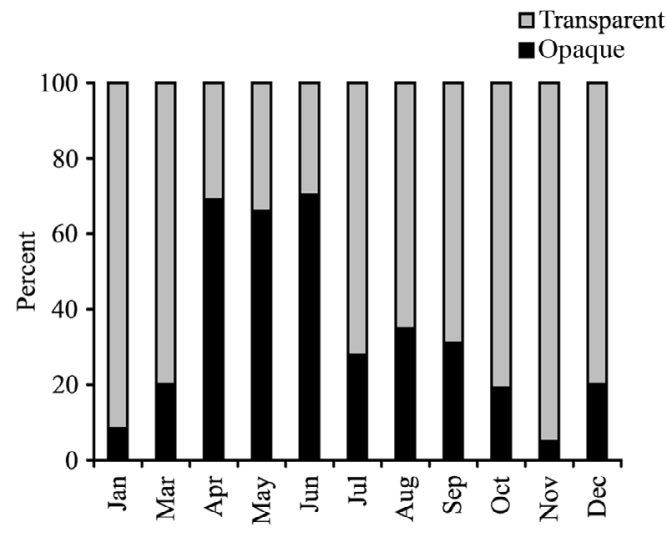

FIGURE 2. Otolith edge analysis of annual formation of bands (opaque versus transparent ring at edge of otolith) of black perch captured each month from January 2004 through November 2004 (February not shown because only one fish was captured in February 2004) and December 2005 through January 2006. Pattern was seen among all age-classes. 


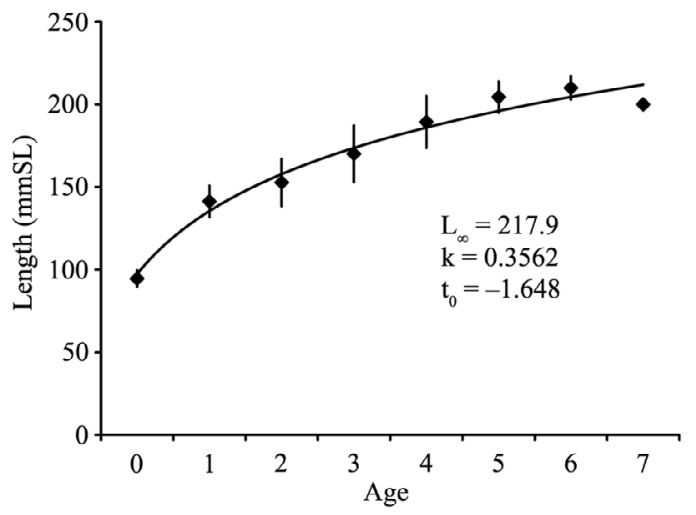

FIgURE 3. Mean length (mm SL) at age for black perch (Embiotoca jacksoni) from southern California. Error bars represent 1 standard deviation. Data were fit to the von Bertalanffy growth equation and the von Bertalanffy parameters are listed.

Three hundred and fifty-seven black perch were used for the age analysis. Black perch grow fastest in their first year, with a mean SL $(\mathrm{mm})$ of $94.60( \pm 8.25)$ and grow approximately $30 \mathrm{~mm}$ SL each year thereafter (Figure 3). The von Bertalanffy equation for all black perch was determined to be $L_{t}=$ $217.9\left(1-e^{-0.3562(t-1.648)}\right)$ (Figure 3). Of the seven age-classes age-class 0 had the smallest range (75-115 $\mathrm{mm} \mathrm{SL}$ ) and age-classes 2 (108-190) and 3 (130-212) both had the highest ranges (Table 2). Growth rates of males and females were not significantly different (ANCOVA, $\quad F=1.23 ; \quad \mathrm{df}=1,341$; $P=.26)$.

TABLE 2

Range of Standard Length (mm) by Age-Class For Black Perch (Embiotoca jacksoni)

\begin{tabular}{lcr}
\hline \hline Age-Class & Range $(\mathrm{mm} \mathrm{SL})$ & $n$ \\
\hline 0 & $75-115$ & 67 \\
1 & $90-165$ & 45 \\
2 & $108-190$ & 128 \\
3 & $130-212$ & 76 \\
4 & $153-220$ & 31 \\
5 & $189-215$ & 5 \\
6 & $200-215$ & 4 \\
7 & 200 & 1 \\
\hline
\end{tabular}

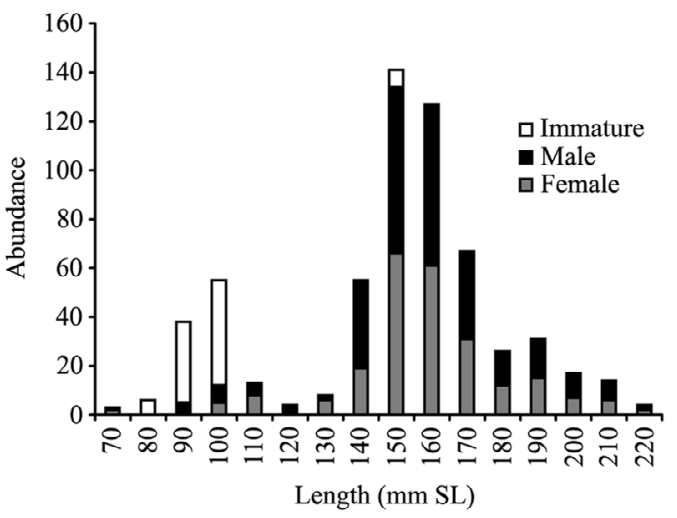

FIgURE 4. Length frequencies of all 614 black perch (Embiotoca jacksoni) collected from January 2004 through November 2004 and December 2005 through January 2006 from all southern California locations, classified by sex.

\section{Sex Composition and Maturity}

Sex or maturity state was determined for 614 black perch throughout all locations and sampling months. As expected for viviparous fishes, the sex ratio of black perch did not differ significantly from a $1: 1$ ratio ( $G$-test, $G=0.23, \mathrm{df}=1, P=.63)$ between females (51\%) and males (49\%). Both sexes were consistently represented throughout the size classes, and immature fish were consistently smaller than $100 \mathrm{~mm}$ SL (Figure 4). Overall, males and females were similar in abundance among age-classes $1-3$. There were apparently more males in age-classes 4 and 5 and more females in age-class 6.

\section{Reproductive Characteristics and Behavior}

Black perch were observed courting from July through November in 2004 and 2005. Behaviors and seasonality of courtship appeared to be indistinguishable among the field sites and between them and the Long Beach Aquarium of the Pacific. During the months of courting, territoriality was not observed, but fish did appear to segregate by size class. Males were never observed courting females smaller than themselves. Courting was never observed taking place at the shallow 5-m isobath in King Harbor because that habitat was dominated by nonreproductive juveniles. 


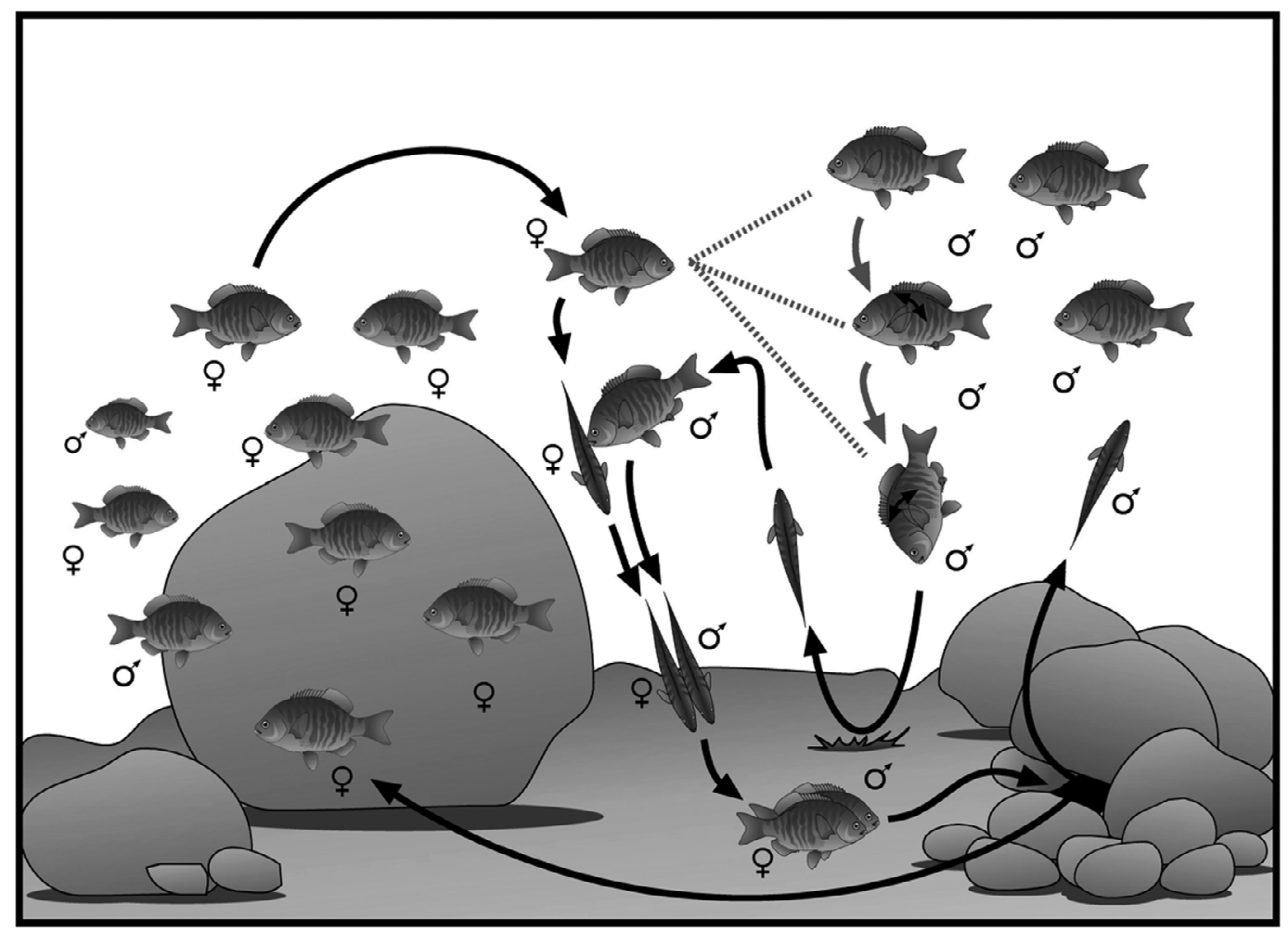

FIGURE 5. Courtship behaviors seen in black perch (Embiotoca jacksoni) in King Harbor, Redondo Beach. Courtship postures consisted of males: (1) raising dorsal fins, (2) raising dorsal fins and fluttering pectoral fins, (3) raising dorsal fins and fluttering pectoral fins with their head pointed downward, (4) males rubbing their body against the substrate, (5) female approaching male, (6) male bumping side of female with its nose, (7) male rubbing against female, (8) male and female enter cave.

Courtship primarily occurred in close proximity to the bottom of the reef $(10 \mathrm{~m})$ at King Harbor around large boulders and across the entire $100-\mathrm{m}$ span of the breakwater studied. Black perch tended to aggregate around one central point (e.g., a boulder) in large groups of up to 20 individuals. These aggregations consisted of males and females swimming around the central point, with males performing courtship rituals at a short distance from the group of females. Never more than five males were seen at one time performing courtship rituals. Courtship postures consisted of males: (1) raising dorsal fins, (2) raising dorsal fins and fluttering pectoral fins, and (3) raising dorsal fins and fluttering pectoral fins with their head pointed downward. Males also would (4) rub the side of their body against any substrate in close proximity or along the bottom of the reef. At that time (5) the female usually approached (Figure 5). Once the female approached, the male would bump the side of the female close to her pelvic fin with his snout and/or rub against the side of her body. After the female appeared receptive, the male would lead her to a nearby cave (Figure 5). Copulation, never observed, was assumed to occur in the cave.

Peaks in male GSI occurred in the same months that courtship was observed, with the largest mean GSI in October (mean GSI = $1.55 \pm 0.06, n=66$ [Figure 6]). Gravid females were first recorded in December, fol- 


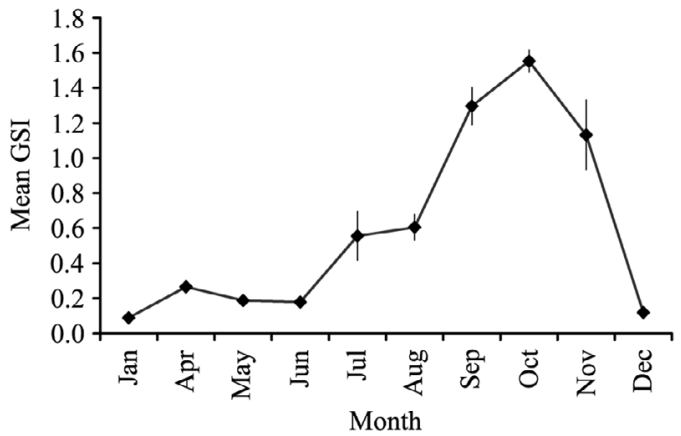

Figure 6. Mean \pm standard error of gonosomatic indices (GSI) for 276 male black perch (Embiotoca jacksoni) from the Southern California Bight by month of capture from January 2004 through November 2004 and from December 2005 through January 2006 (February and March 2004 were excluded due to low sample size). Data from January 2004 and January 2006 were pooled.

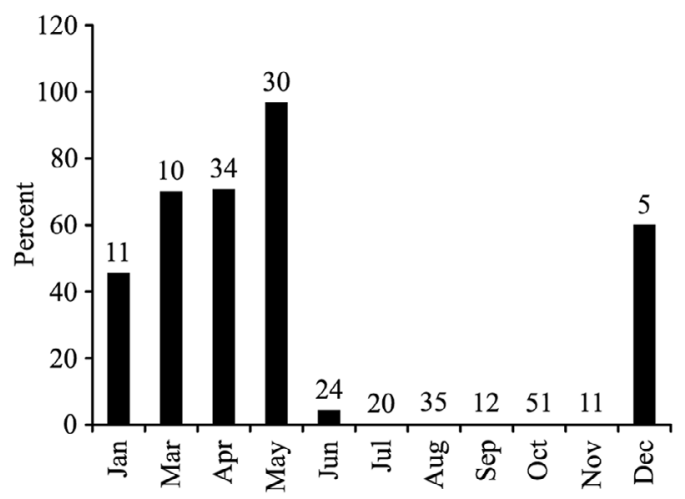

Figure 7. Percentage of pregnant female black perch (Embiotoca jacksoni) in southern California by month. Numbers above bars represent total number of females captured for each month. Due to low sample size $(n=1)$ February is not shown.

lowing the decline in male GSI, and were present through June, indicating an overall 5- to 6-month gestation period (Figure 7). Gestating females ranged from 135 to 190 $\mathrm{mm} \quad \mathrm{SL} \quad($ mean $=163.44 \pm 0.104, \quad n=70)$ and carried between 4 and 17 embryos $($ mean $=8.73 \pm 0.391)$. The highest percentage of gestating females occurred in May $(96.67 \%, n=30)$, with the lowest occurring in June ( $4.17 \%, n=24$ [Figure 7]). Finally, a

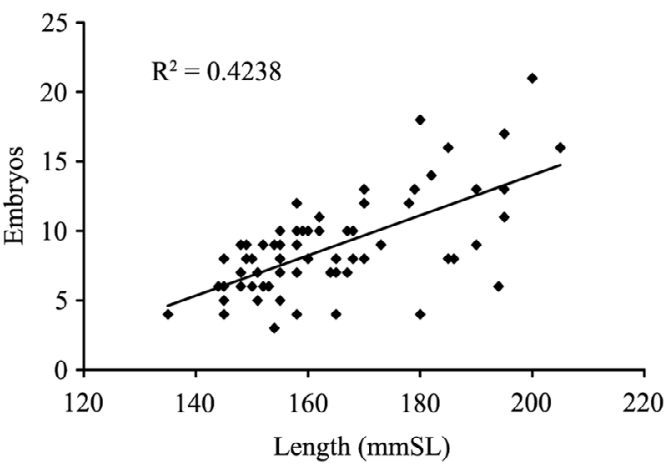

FiguRE 8. Relationship of number of embryos to length $(\mathrm{mm} \mathrm{SL})$ of female black perch (Embiotoca jacksoni). Larger females tended to carry more embryos (number of embryos $=0.145(\mathrm{SL})-14.9 ; P=.0010)$.

positive relationship between length of the female and the number of embryos (regression, $R^{2}=0.4238 ; \quad F=50.016 ; \quad \mathrm{df}=1,68$; $P=.0010)$ was found, with the larger females carrying more embryos (Figure 8).

\section{DISCUSSION}

\section{Life History}

Black perch are fast-growing, short-lived fish. The fastest growth occurred in the first years, when size approximately doubled, and then growth tapered off to $\sim 30 \mathrm{~mm}$ SL each year thereafter. Sexes did not differ in size among age-classes, and both sexes had the same life span.

This study showed a decline in abundance of age-class 4, and the maximum SL for each age-class was smaller than that from Isaacson and Isaacson (1966). Differences in length between the studies probably result from collecting in widely separated regions. In this study we collected specimens throughout the Southern California Bight, whereas Isaacson and Isaacson (1966) collected specimens from both Long Beach (southern California) and San Francisco (northern California). Species of surfperches often differ in their age and growth parameters between northern and southern California, with northern populations having a larger body size than southern populations (DeMartini et al. 1983). 
Isaacson and Isaacson (1966) did not separate individuals by location; therefore, the largest individuals could very well have been solely from the northern California population. However, the possibility remains that the differences in fish length could represent true differences within southern California between this study and that of Isaacson and Isaacson (1966), indicating that the black perch population in southern California has decreased in length overall over the past 40 yr for some reason.

The paucity of black perch in age-classes 5 and greater in this study may indicate that the adult population is not surviving much past age four because of fishing pressure, predation, or habitat/food loss in southern California.

\section{Reproductive Characteristics and Behavior}

Black perch at King Harbor, Redondo Beach, courted from late July through early November. Black perch thus have the longest documented season of courtship among surfperches. Shiner perch court from June through August (Hubbs 1921, Wiebe 1968b, Bane 1970), and white seaperch only court from October to November (Goldberg 1978). The difference of the time frame of courtship for black perch compared with other surfperches could be an indication that black perch are storing sperm during the breeding season, because gestating females were not observed until 6 months after courtship originally began. However, further study is needed to test this hypothesis.

Black perch are similar to shiner perch in that both species court in large aggregations. However, this study demonstrated that black perch relocate to deeper water whereas shiner perch relocate to shallower water for reproduction. Black perch are known to change their distribution from shallower water during the winter and spring to deeper water during the late summer and fall at King Harbor, Redondo Beach, because of increase in temperature during the summer and fall months (Terry and Stephens 1976). The present study suggests that temperature may not be the only factor influencing depth dis- tributions because reproductive behaviors may play a role. Our data suggest that black perch migrated to deeper water for courtship and returned to shallower water thereafter. Black perch might migrate to deeper water for courting because of the topography of the reef in deeper depths. In King Harbor, the majority of the caves and large boulders are in deeper water, and this type of habitat could possibly provide protection from predators during courtship.

During courtship, males were the primary aggressors and were never seen courting females significantly smaller or larger than themselves, similar to most surfperches (Hubbs 1917, 1921, Rechnitzer and Limbaugh 1952, Weibe 1968a, $b$, Bane 1970, DeMartini 1988). Females appear to exercise the primary selection of mates because males performed courtship rituals within full view of many females and the females then chose a particular male. Female mate selection also occurs among white seaperch (Goldberg 1978) and blue rockfish (Helvey 1982). Those studies support that female choice is prevalent among viviparous species, and it is probably a result of the female reproductive effort exceeding the male's contribution (Helvey 1982).

Although black perch have been reported as being territorial (Hixon 1981), this behavior was not observed during times of courtship. The data reported here support the observation that black perch are not territorial at King Harbor (Pondella et al. 2002). The lack of territorial behavior could result from the large population present in King Harbor. The population of black perch at King Harbor may exceed the density at which holding territories is beneficial. Further work is necessary to determine if density does have an effect on territoriality of black perch in King Harbor.

Patterns in male black perch gonosomatic index as well as the time of year when gestating females were recorded both indicated that reproduction occurred about the same time throughout the Southern California Bight as observed in King Harbor. Furthermore, male gonadal indices dropped at the same time gestation started, indicating that black perch 
are not storing sperm for as long as other surfperches, such as shiner perch (Hubbs 1917, Weibe 1968b).

Embryo number increased with female size, which is common among surfperches (Behrens 1977, Goldberg 1978, DeMartini et al. 1983, Baltz 1984). However, the mean number of embryos $(8.73 \pm 0.391)$ and the number of embryos $(n=17)$ reported in this study were lower then previously reported $($ mean $=14.4$, total $=31 \quad$ [Behrens 1977]). The differences between the mean and total number of embryos between the two studies could be due to the fact that the majority of females in the study reported here were captured with gill nets. It was apparent from personal observations (B.F.) that some females abort their young when captured.

The youngest female reported in this study to be sexually mature was $1 \mathrm{yr}$ old. Female black perch also mature at age one in San Francisco and Long Beach (Isaacson and Isaacson 1966) and not until age two at Princeton Harbor, Mateo County (Behrens 1977, Baltz 1984). The discrepancies between these ages of maturity may reflect differences between northern and southern California populations. In addition to being larger in northern California surfperches have been shown to delay maturity and have higher fecundity compared with southern California populations (DeMartini et al. 1983). Behrens (1977) collected black perch from Princeton Harbor, Mateo County, in northern California and recorded the youngest gestating female at age two with females gestating from April through mid-November. On the other hand, Isaacson and Isaacson (1966) collected black perch from Long Beach in southern California and San Francisco in northern California and reported their youngest gestating female to be age one with females gestating year-round. The most reasonable explanation for the discrepancy among studies is that black perch gestate at different times of the year in northern and southern California. Further, females in northern California appear to delay maturity to age two. Isaacson and Isaacson (1966) probably reported gestating females throughout the year because they did not distinguish between northern and southern California populations in their study.

Both genetic and environmental factors have been suggested to influence the differences in life history and reproductive behaviors of embiotocids (DeMartini et al. 1983). Two distinctive clades of black perch have been demonstrated, with the primary separation between the two clades occurring in Santa Monica Bay (Bernardi 2000, 2005). The study reported here included specimens from both north and south of Santa Monica Bay, and further investigation of these data indicated that black perch from all locations exhibited similar life history traits. Therefore, the study reported here does not support the hypothesis that genetic differences affect the behavior and life history of black perch throughout the population in the Southern California Bight. Although further investigation is needed to determine the actual cause of differences between seasonality of reproduction, age of maturity, and length, a plausible hypothesis is that the differences could be a result of the different environmental factors that black perch experience throughout their range. The black perch reported by Behrens (1977) and Isaacson and Isaacson (1966) in northern California were from bays and estuaries, and the black perch collected from southern California in the study reported here were primarily from rocky reefs and kelp beds. Although kelp beds have a high level of productivity, bays and estuaries are thought to have the greatest availability of food (Allen et al. 2006). Furthermore, species in northern California experience colder temperatures than species in southern California. A combination of the different types of habitats and seasonality or increase/decrease of productivity and/or temperature may explain the differences between the northern and southern populations of black perch.

\section{ACKNOWLEDGMENTS}

We thank Mark Steele and David Gray for their valuable input throughout the course of the study, especially Mark Steele for his assistance with statistics. We also thank Edward 
DeMartini for reviewing the paper and providing helpful comments to improve the manuscript. Thanks also to the many people that participated in specimen collection and diving.

\section{Literature Cited}

Allen, L. G., and D. J. Pondella II. 2006. Surf zone, coastal pelagic zone, and harbors. Pages 149-166 in L. G. Allen, D. J. Pondella II, and M. H. Horn, eds. The ecology of marine fishes: California and adjacent waters. University of California Press, Berkeley.

Allen, L. G., M. M. Yoklavich, G. M. Cailliet, and M. H. Horn. 2006. Bays and estuaries. Pages 119-147 in L. G. Allen, D. J. Pondella II, and M. H. Horn, eds. The ecology of marine fishes: California and adjacent waters. University of California Press, Berkeley.

Anderson, R. D., and C. F. Bryan. 1970. Age and growth of three surfperches (Embiotocidae) from Humboldt Bay, California. Trans. Am. Fish. Soc. 3:475-482.

Baltz, D. M. 1984. Life history variation among female surfperches (Perciformes: Embiotocidae). Environ. Biol. Fishes 10: 259-171.

Bane, G. W. 1970. Studies on the shiner perch, Cymatogaster aggregata Gibbons, in upper Newport Bay. Wasmann J. Biol. 28:22-25.

Behrens, D. W. 1977. Fecundity and reproduction of the viviparous perches Hypsurus caryi (Agassiz) and Embiotoca jacksoni Agassiz. Calif. Fish Game 63:234-252.

Bernardi, G. 2000. Barriers to gene flow in Embiotoca jacksoni, a marine fish lacking a pelagic larval stage. Evolution 54:226237.

. 2005. Phylogeography and demography of sympatric sister surfperch species, Embiotoca jacksoni and E. lateralis along the California coast: Historical versus ecological factors. Evolution 59:386-394.

Carlisle, J. G., Jr., C. H. Turner, and E. E. Ebert. 1964. Artificial habitat in the marine environment. Calif. Dep. Fish Game Fish Bull. 124.
Craig, M. T., D. J. Pondella II, and J. C. Hafner. 1999. Analysis of age and growth in two eastern pacific groupers (Serranidae: Epinephelinae). Bull. Mar. Sci. 65:807814.

DeMartini, E. E. 1969. A correlative study of the ecology and comparative feeding mechanism morphology of the Embiotocidae (surf-fishes) as evidence of the family's adaptive radiation into available ecological niches. Wasmann J. Biol. 27:177-247.

- 1988. Size-assortive courtship and competition in two embiotocid fishes. Copeia 2:336-344.

DeMartini, E. E., T. O. Moore, and K. M. Plummer. 1983. Reproductive and growth dynamics of Hyperprosopon argenteum (Embiotocidae) near San Diego, California. Environ. Biol. Fishes 8:29-38.

Ebeling, A. W., and D. R. Laur. 1985. The influence of plant cover on surfperch abundance at an offshore temperate reef. Environ. Biol. Fishes 12:169-179.

FISHPARM. 1989. FISHPARM v3.0S. Elsevier Scientific Publishers, Bronxville, New York.

Goldberg, S. R. 1978. Reproductive cycle of white seaperch, Phanerodon furcatus (Embiotocidae). Copeia 2:335-336.

Helvey, M. 1982. First observations of courtship behavior in rockfish, Genus Sebastes. Copeia 4:763-770.

Hixon, M. A. 1981. An experimental analysis of territoriality in the reef fish Embiotoca jacksoni (Embiotocidae). Copeia 3:653665.

Holbrook, S. J., R. J. Schmitt, and J. S. Stephens Jr. 1997. Changes in an assemblage of temperate reef fishes associated with a climate shift. Ecol. Appl. 7:1299-1310.

Horn, M. H., L. G. Allen, and R. N. Lea. 2006. Biogeography. Pages 3-25 in L. G. Allen, D. J. Pondella II, and M. H. Horn, eds. The ecology of marine fishes: California and adjacent waters. University of California Press, Berkeley.

Hubbs, C. L. 1917. The breeding habits of the viviparous perch, Cymtogaster aggregata. Copeia 47:72-74.

. 1921. The ecology and life-history of Amphigonopterus aurora and of other vivip- 
arous perches of California. Biol. Bull. (Woods Hole) 40:181-209.

Isaacson, P. A., and D. M. Isaacson. 1966. Notes on the life history of the black perch, Embiotoca jacksoni Agassiz. Trans. Am. Fish. Soc. 95:107-109.

Karpov, K. A., D. P. Albin, and W. H. Van Buskirk. 1995. The marine recreational fishery in northern and central California: A historical comparison (1958-86), status of stocks (1980-86), and effects of changes in the California Current. Calif. Dep. Fish Game Fish Bull. 176.

Leet, W. S., C. M. Dewees, R. Klingbeil, and E. J. Larson, eds. 2001. California's living marine resources: A status report. Pages 236-240. California Resources Agency, California Department of Fish and Game, Sacramento.

Miller, D. J., and R. N. Lea. 1972. Guide to the coastal marine fishes of California. Calif. Dep. Fish Game Fish Bull. 157.

Pondella, D. J., II, J. S. Stephens Jr., and M. T. Craig. 2002. Fish production of a temperate artificial reef based on the density of embiotocids (Teleostei: Perciformes). ICES J. Mar. Sci. 59:S88-93.

Rechnitzer, A. B., and C. Limbaugh. 1952.
Breeding habits of Hyperprosopon argenteum: A viviparous fish of California. Copeia 1952:41-42.

StatSoft. 2007. STATISTICA v6.1. StatSoft, Inc., Tulsa, Oklahoma.

Stephens, J. S., Jr., R. J. Larson, and D. J. Pondella II. 2006. Rocky reefs and kelp beds. Pages 227-252 in L. G. Allen, D. J. Pondella II, and M. H. Horn, eds. The ecology of marine fishes: California and adjacent waters. University of California Press, Berkeley.

SYSTAT Software. 1999. SYSTAT 9. Systat Software, Inc., San Jose, California.

Terry, C. B., and J. S. Stephens Jr. 1976. A study of the orientation of selected embiotocid fishes to depth and shifting seasonal vertical temperature gradients. Bull. South. Calif. Acad. Sci. 75:170-183.

Wiebe, J. P. 1968a. The effects of temperature and daylength on the reproductive physiology of the viviparous seaperch, Cymatogaster aggregata Gibbons. Can. J. Zool. 46:1207-1219.

. 1968b. The reproductive cycle of the viviparous seaperch, Cymatogaster aggregata Gibbons. Can. J. Zool. 46:12211234. 
